\title{
THE DEVELOPMENT OF AN EXPLOSION PROTECTION SYSTEM IN THE STARTING AIR MANIFOLD OF A HIGH POWER ENGINE
}

doi: $\quad 10.2478 /$ czoto-2019-0004

Date of submission of the article to the Editor: 27/11/2018

Date of acceptance of the article by the Editor: 31/12/2018

\author{
Leszek Chybowski ${ }^{1}$ - orcid id: 0000-0003-0245-3946 \\ Damian Kazienko ${ }^{1}$ - orcid id: 0000-0002-7331-7960 \\ ${ }^{1}$ Maritime University of Szczecin, Poland, I.chybowski@am.szczecin.pl
}

\begin{abstract}
In this paper, the authors have discussed the subject of fire and explosion hazards during the operation of a modern ship's high-power internal combustion engines. The causes of the occurrence of and the methods of preventing explosions in the starting manifolds of modern piston combustion engines equipped with a pneumatic starting system, with starting valves on the cylinder heads, have been specified. The concept of an active system for monitoring the technical condition of the starting valves has been presented in order to quickly diagnose leakages and reduce the risk of explosion. A conceptual design of a prototype of a non-invasive, new generation leak detector for starting valves and its technical design have been presented. Exemplary implementations of the prototype detector have been shown and its selected functionalities have been discussed. This paper has ended with an assessment of the possibility of further development and the applications of this device.
\end{abstract}

Keywords: explosion protection, leakage detector for starting valves, machine diagnostics, engine explosions, active monitoring system

\section{INTRODUCTION}

The operation of modern high-power combustion engines is inevitably associated with the risk of fire or explosion. In Figure 1, the example of a slow-running engine has shown that there is a hazard present in practically the entire engine environment, and it refers to, among other things, explosions in the crankcases (Chybowski et al, 2015), turbocharger explosions (Chybowski and Matuszak, 2007), fires in the flushing air reservoirs and piston spaces (Strojecki, 2011), fires in the exhaust manifolds (Chmura, 2012) and fires resulting from leaks of flammable substances (Bistrović and Ristov, 2017; Gawdzińska et al., 2015; Kwiecińska, 2015).

One of the elements of marine engines that are at risk of explosion is the starting air manifold. Explosions in the starting air manifolds of modern large power engines are characterized by their rapid occurrence (Chybowski and Grzebieniak, 2009c). Despite significant technical progress (Marine Diesels, 2018b; Marine Insight, 2018) (safety valves, bursting discs, fire traps, etc.) and improvements in operating procedures, incidents of this type still occur leading to injury or death of crew members (Marine 
Diesels, 2018a; Ptak et al., 2017a). Fires and explosions due to dynamic loads can lead to damage to the ship's components (Jambor et. al., 2018; Gawdzińska et al., 2017; Grabian et al. 2008; Kwiecińska, 2015; Ulewicz and Novy, 2017; Zapłata and Pajor, 2016) and finally to its temporary decommissioning.

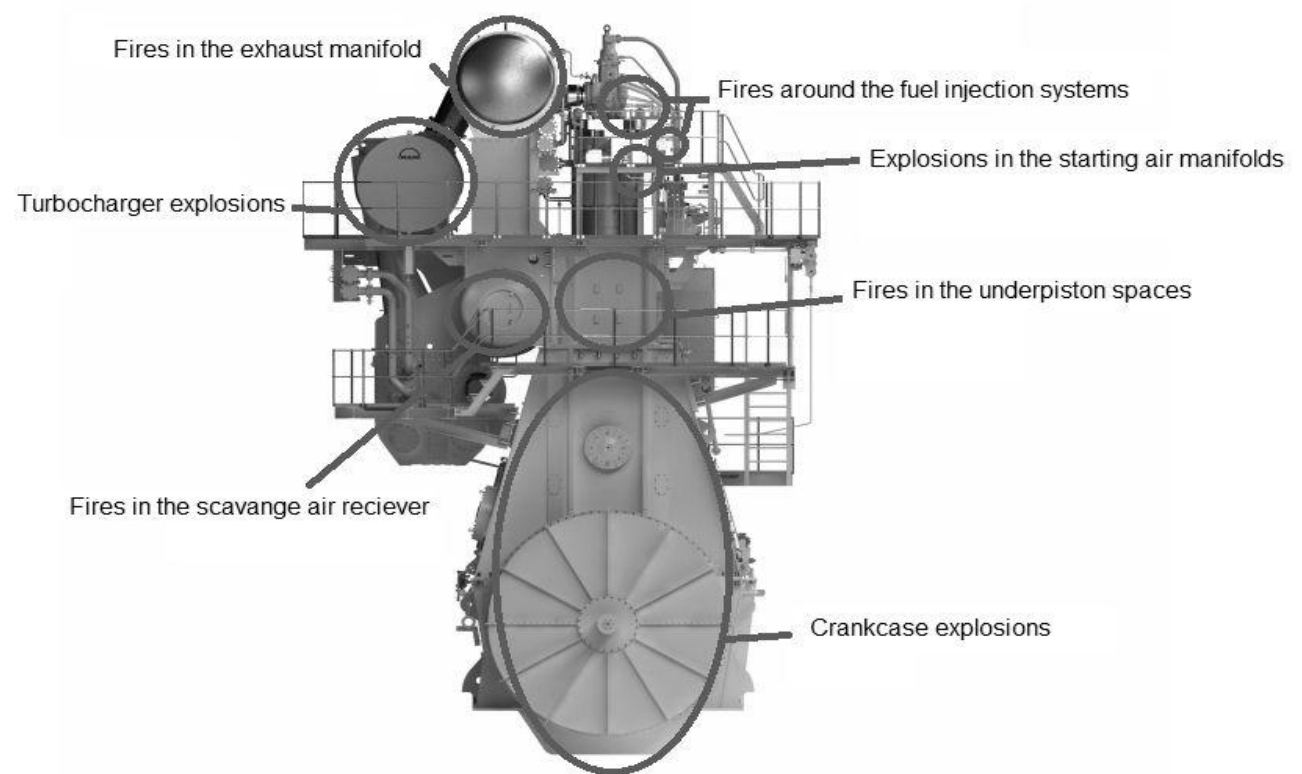

Fig. 1. Functional elements of a high-power low-speed engine at risk of explosion or fire

Examples of slow-running engine damage associated with a 2013 explosion (Myanmar Marine Engineers, 2018) in the starting air manifold at the starting valve on the 11th cylinder system of the main engine have been shown in Figure 2.

a)

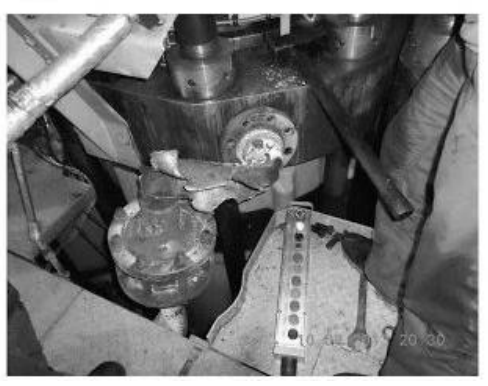

b)

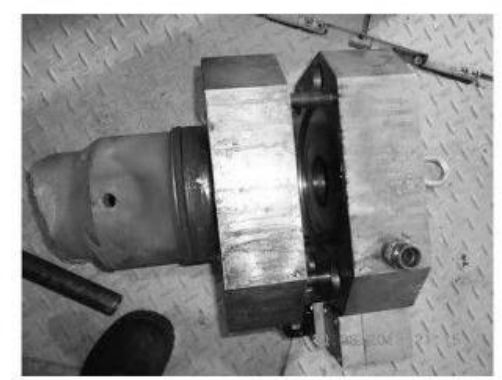

Fig. 2. Effects of explosion in the starting air manifold (Myanmar Marine Engineers, 2018); a) starting air pipe after explosion, b) starting air valve after explosion

The continued presence of this hazard is due to the complex multi-factorial nature of these explosions, including in particular their source of combustible material, such as (Chybowski and Grzebieniak, 2009c):

- the ignition of fuel or cylinder oil which has penetrated from a specific cylinder system through a leaking starting valve during operation or during start-up if fuel has accumulated while the cylinder was idle;

- the ignition of an excessive amount of lubricating oil that accumulated in the starting manifold, which entered there together with the air from the starting air compressor in the case of worn piston scraper rings of the compressor pistons or even as a result of the compressor suction of oil vapours located in the marine engine room environment; 
- the ignition of carbon deposits formed as a result of thermal decomposition of the above mentioned petroleum substances on the heated walls of the starting air manifold.

The source of heat that triggers an explosion can be the working medium from the cylinders that enters through a leaking starting valve or self-ignition caused by a rise in temperature during a rapid inflow (compression) of high-pressure starting air into the starting manifold during start-up, resulting in a flammable mixture at a temperature of approximately $400^{\circ} \mathrm{C}$ (Yuzhong and Sasaki, 2003).

As can be deduced from the above comparison, the important factor that allows for the reduction in the probability of an explosion is the monitoring of the technical condition (tightness) of the starting valves installed on the heads of the individual cylinder systems (Kazienko, 2018; Piotrowski and Witkowski, 2003). The tightness of the valves will prevent the accumulation of flammable liquids in the engine starting manifold and the supply of heat from the combustion chamber, which may cause ignition. One of the solutions proposed for monitoring the technical condition of the starting valves is a leakage detector (Chybowski and Grzebieniak, 2009a), which uses the measurement of the temperatures between the starting valves and the starting air manifold which is able to detect a potential leak due to an internal leakage in one of the starting valves. General assumptions concerning the construction of the device, as well as an example analysis of the measurement values and simulations of the detector's operation have been presented by Chybowski and Grzebieniak (2009b). The following publication presents the results of the development of an improved version of the detector. The new detector is equipped with new features and functionalities.

\section{LEAKAGE DETECTOR CONCEPT FOR STARTING VALVES}

According to the concept from 2009, the system can be manufactured in various versions, i.e. in an exemplary solution, the Pt100 resistance sensors or thermocouples fixed to the compressed air pipelines or embedded in a protective cover that can be used as temperature sensors. The algorithmic block can be realized in the form of a personal computer or microcontroller. The operation of the basic algorithm implemented by the signal processing block has been shown in Fig. 3.

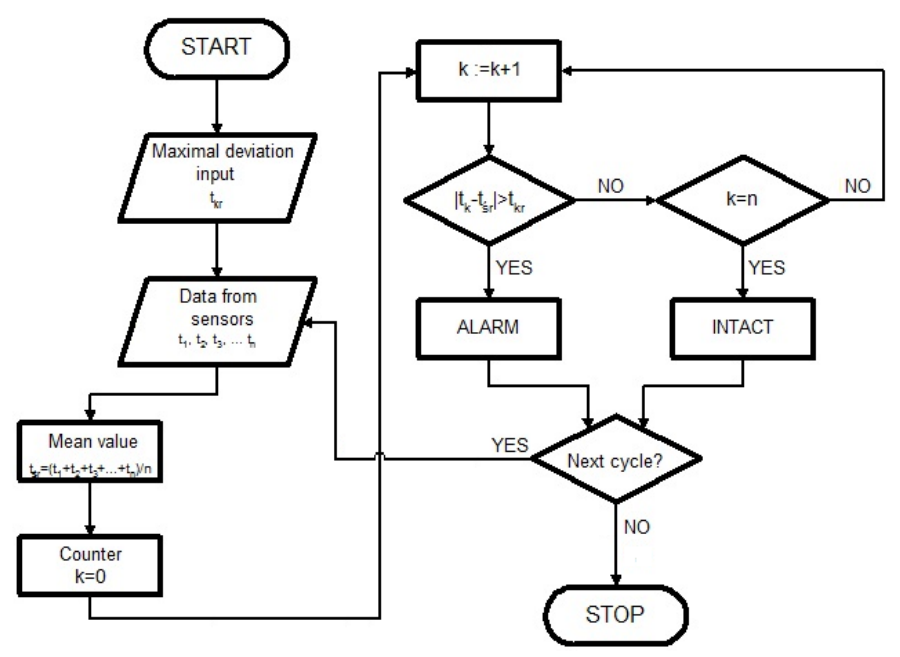

Fig. 3. Signal processing block in the marine engine starting valve diagnostic system (Chybowski and Grzebieniak, 2009a) 
The software operates in an algorithmic block and its operation includes (Chybowski and Grzebieniak, 2009a): signal processing from temperature sensors, calculating the average temperature of all the sensors and determining the absolute differences between the signal value of each sensor and the calculated average value. If the difference exceeds a critical value of $25^{\circ} \mathrm{C}$, the system generates a suspicion of leakage in a particular starting valve.

In 2018 the authors carried out an analysis of the needs of the end users (ship engine room operators) and an assessment of the possibility of using connectors to monitor the systems of modern ship engine rooms. As a result of this research being carried out, the assumptions for the development of a detection system and a prototype of the device were formulated. It was assumed that the device will enable multichannel temperature measurement with the use of resistive sensors. The device will be compatible with the engine supervision system and optional additional software to monitor the operation of the detector. The number of new functionalities was formulated (Chybowski and Kazienko, 2018a; Chybowski and Kazienko, 2018b). The interface of the device must support:

- selection of the channels where the measurement is to be carried out by means of switches;

- adjustment of the maximum permissible deviation of the signal's value from the average value by means of a potentiometer in the range of $0-100 \%$,

- adjustment of the sampling period of the signals by means of a potentiometer in the range of $0.5-5 \mathrm{~s}$;

- notifications about the status of the device by means of an LCD display of $2 \times 15$ characters informing the user about the enabled channels, the pre-set sampling period, the pre-set permissible deviation of the signal's value from the average value and the operating states "OK", "Alarm" and when the engine is stopped "Engine stopped".

In addition, the device will be equipped with a $5 \mathrm{~V}$ signal output to the marine engine room monitoring system (IMAS) and a signal input from the engine, informing the detector as to whether the engine is running, and thus whether the system will work. The latter functionality will work in conjunction with an additional bypass switch used for testing the detector when the engine is idle. The device will be powered by a 9VDC battery or an external 220VAC/5-9VDC AC power supply.

\section{RESULTS}

On the basis of the initial presented assumptions, the authors designed a device based on an Arduino MEGA 2560 microcontroller, the diagram of which has been shown in Figure 5. The computer-level detector oversight software was developed in the Processing 3 environment which is based on JavaScript. The device can also be built on the basis of other programmable controllers available on the market.

The controller reads the information about temperatures from the Pt100 resistance sensors through a block of input resistors with resistance $R$. Selection of the measurement channel is made by means of the switches S1 to S9. The determination of the permissible absolute deviation from the average value of the measurement channels activated for operation can be carried out with the potentiometer "Max. Dev." and the set period of sampling signals can be set with the "Sampling" potentiometer. Information about the status of the device will be displayed on the LCM1602LCD display. The device is switched on via the main switch "S. Power". The detector is informed about the operating status of the diagnosed object by means of a signal delivered to the detector via the "Engine status" input. The detector operates when the "Engine status" input signal is 
not equal to 0 . The "Engine status" input status as different from 0 can be simulated using the "Engine status" switch (below S9 in the Figure 5). Activation of the "Engine status" switch will cause the detector to continuously analyse the sensor signals without taking into account whether the diagnosed scattered object is in its operating state or it is idle. When the controller registers that the value of any signal or signals from the connected sensors is greater than a set percentage of the permissible absolute deviation of the signal value, an alarm will be activated.

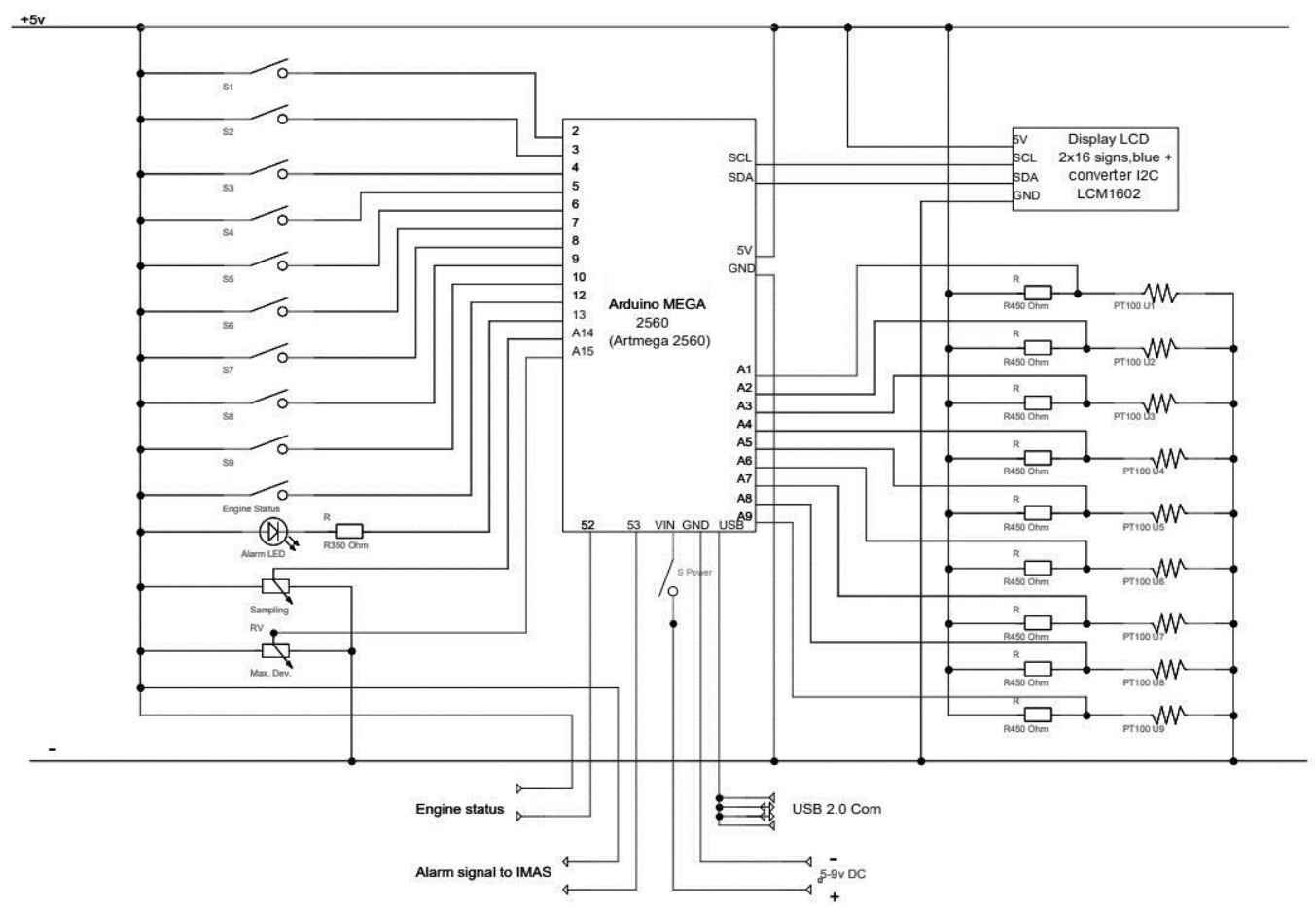

Fig. 5. Conceptual schematic diagram of the leak detector for starting valves

It was assumed that the detector's casing is a spatial element, which will be closed on all sides, with the elements on the front panel as shown in Figure 6.
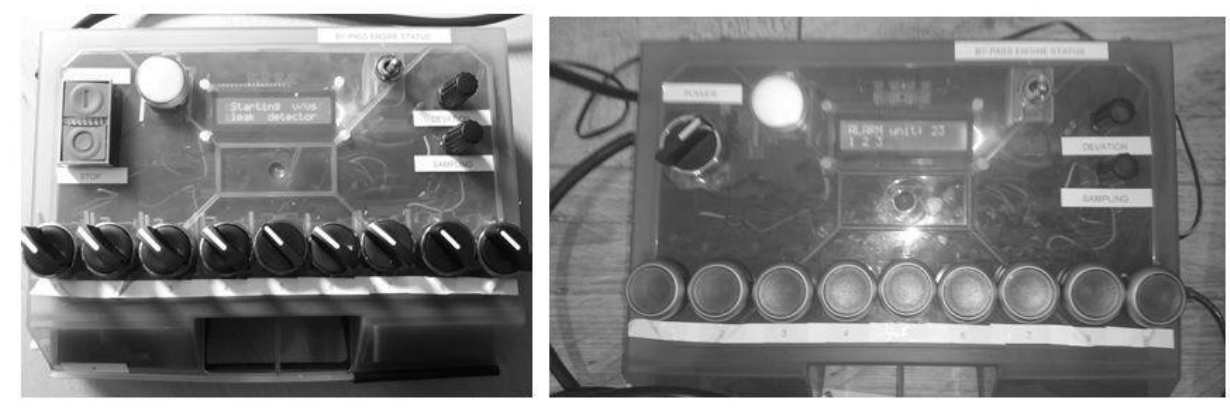

Fig. 6. Two versions of the front panel of the leak detector for starting valves

In the prototype that was developed, on one row there were channel switches that enabled the selection of the sensors used during the operation of the diagnostic system; the information display, main switch, alarm light indication, as well as the potentiometers for the regulation of the sampling period and the regulation of the absolute value of the percentage of permissible deviation of the measured signal value from the average value 
of all the sensors and the by-pass to stop the measurements while the engine is not working so the device can be tested while waiting at the harbour.

\section{DISCUSSION}

The prototype was calibrated using a calibration furnace. The measured values of the signals for the individual measurement channels, on which a two-wire Pt100 Noris TH31 resistance sensor was installed, were connected with a $1 \mathrm{~m}$ long cable with copper cores of $1 \mathrm{~mm}^{2}$ cross-section. An example of the calibration for channel 1 has been shown in Figure 7.

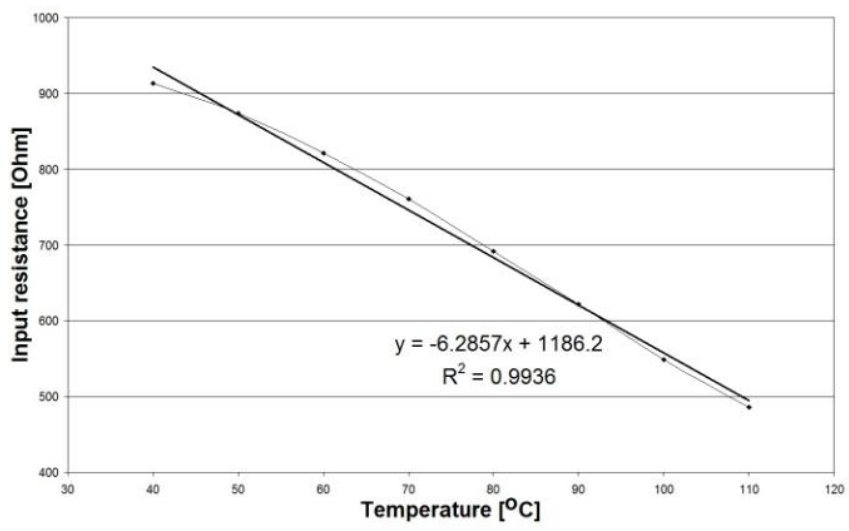

Fig. 7. Standard characteristics of channel 1 of the detector measured on the reference bench

On the basis of the analysis conducted for the values of the resistance signals registered by the microcontroller for a sensor changing temperature in the range of $40-110^{\circ} \mathrm{C}$, a standard characteristic for which the approximation equations of the first degree at the adjustment above $R^{2}=0.99$, which were assumed to be sufficient for practical applications, were prepared. Equations for all the channels were implemented in the microcontroller firmware.

The detector interacts via a USB cable with a dedicated program monitoring the status of the device. The view of the user interface of the monitoring program has been shown in Figure 8.

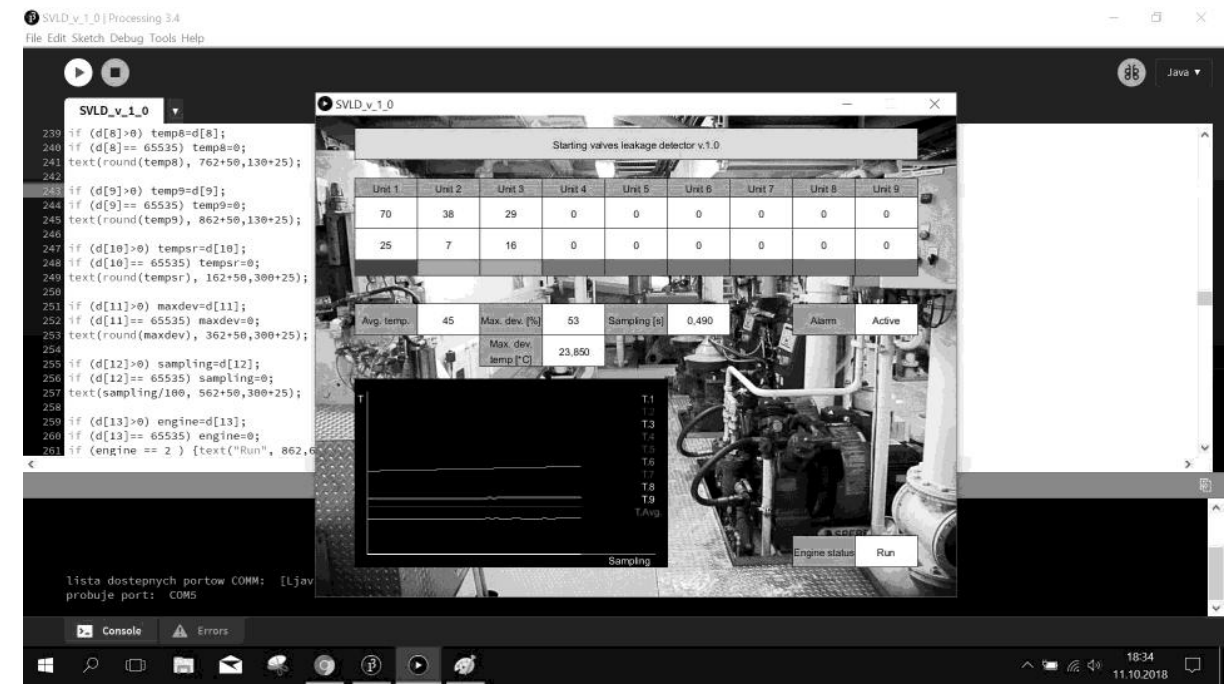

Fig. 8. Graphical interface of an external system supervising the operation of the detector 
In addition, the software allows the value of the momentary deviations of the signal values from the average value, obtained from the connected measurement channels, to be tracked. The system also makes it possible to record the changes in the signal values over time and present them in the form of charts. The use of the graphical interface is optional and the detector is fully functional even when it is not connected to a computer. Software tests carried out as verification of the entered calibration characteristics verified the conformity of the indications on the front panel with the data presented on the computer screen.

\section{CONCLUSION}

The detector presented in this paper has been proven to perform the measurement and information functions in the intended manner. The authors assume that the next step in the development of the presented solution will be the installation of a detector on a marine engine and testing it in real operating conditions. However, a further increase in the TRL will depend on the funds that can be raised for industrial research. At the moment the described solution has been submitted for industrial protection (Chybowski and Kazienko, 2018a; Chybowski and Kazienko, 2018b).

It should be noted that the solution presented in the paper is characterized by a high degree of universality. Similar to the diagnosis of starting valves, it is possible to record disturbances in the high-temperature water cooling of individual engine cylinder systems (Bejger and Drzewieniecki, 2015; Bejger et al., 2018, Ptak et al. 2017b), disturbances in water/oil cooling of pistons, deviations in exhaust gas temperature at the outlet of engine cylinders or the lubrication oil temperature of low speed engines. In all the cases mentioned above the system will be exactly the same, the differences will only be the number and type of sensors and the possible settings of the device (Bejger and Gawdzińska, 2011; Derlukiewicz et al., 2016; Majewski et al., 2018; Sakow et al., 2018).

The solution presented in this paper can not only supervise temperature but also pressure, flow, stress, velocity, position, etc. It is important that the supervised system is characterized by a multiple of the diagnosed functional systems here: marine engine cylinders. This detector can therefore be used in production and processing systems of various types.

\section{ACKNOWLEDGMENTS}

The research presented in this article was carried out under the Grant of the Ministry of Science and Higher Education of Poland $\mathrm{nr}$ 1/S/IESO/17: "Increasing operational effectiveness of complex technical systems by systematic development and implementation of innovations using novel materials and modifying the object's structure" performed at the Maritime University of Szczecin, Poland.

\section{REFERENCES}

Bejger, A., Chybowski, L., Gawdzińska K., 2018. Utilising elastic waves of acoustic emission to assess the condition of spray nozzles in a marine diesel engine. Journal of Marine Engineering and Technology, 17(3), 153-159, DOI: 10.1080/20464177.2018.1492361.

Bejger A., Drzewieniecki J., 2015. Analysis of tribological processes occuring in precision pairs based on example of fuel injection pumps of marine diesel engines. Scientific Journals of the Maritime University of Szczecin, Zeszyty Naukowe Akademii Morskiej w Szczecinie, 41(113), 9-16. 
Bejger A., Gawdzińska K., 2011. Identification of structural defects of metal composite castings with the use of elastic waves. Archives of Metallurgy and Materials, 56(1), 129-133, DOI: 10.2478/v10172-011-0014-z.

Bistrović, M., Ristov, P., 2017. Economic justification for the new approach of using videobased smoke detection with the aim of decreasing total costs incurred by the untimely detection of fires on ships. Scientific Journals of the Maritime University of Szczecin, Zeszyty Naukowe Akademii Morskiej w Szczecinie, 51(123), 21-27, DOI: $10.17402 / 226$.

Chmura, S., 2012. Charakterystyka metod zapobiegania i usuwania pożarów w kolektorach wydechowych wolnoobrotowych silników głównych. B.Sc. thesis, supervisor: Leszek Chybowski. Maritime University of Szczecin, Faculty of Marine Engineering, IESO, Szczecin.

Chybowski, L., Matuszak, Z., 2007. Marine Auxuliary Diesel Engine Turbocharger Damage (Explosion) Cause Analysis. Journal of Polish CIMAC, 2(2), 33-40.

Chybowski, L., Grzebieniak, R., 2009a. Method and system for diagnosing the condition of starting air valves of a Diesel engine, preferably the ship's engine. Patent: PL 217302 B1 - Polish Patent Office.

Chybowski, L., Grzebieniak, R., 2009b. Metoda oceny stanu technicznego zaworów rozruchowych wysokoprężnego silnika okrętowego. Ekonomika i Organizacja Przedsiębiorstwa, 5(712), CD-ROM.

Chybowski, L., Grzebieniak, R., 2009c. Zagrożenie eksplozyjne w układach rozruchowych okrętowych silników wysokoprężnych. Ekonomika i Organizacja Przedsiębiorstwa, 5(712), CD-ROM.

Chybowski, L., Gawdzińska. K., Ślesicki, O., Patejuk, K., Nowosad, G., 2015. An engine room simulator as an educational tool for marine engineers relating to explosion and fire prevention of marine diesel engines. Scientific Journals of the Maritime University of Szczecin, Zeszyty Naukowe Akademii Morskiej w Szczecinie, 43(115), 15-21, DOI: $10.17402 / 034$.

Chybowski, L., Kazienko, D., 2018a. Electronic detector of deviations of signals from sensors monitoring the state of the diagnosed object and the method of detection. Patent application: P.427648 - Polish Patent Office.

Chybowski, L., Kazienko, D., 2018b. Housing and interface of the detector of deviation of diagnostic signals. Industrial design application. 20.11.2018 - Polish Patent Office.

Derlukiewicz, D., Ptak, M., Koziołek, S., 2016. Proactive failure prevention by humanmachine interface in remote-controlled demolition robots. Advances in Intelligent Systems and Computing, 445, 711-720.

Gawdzińska, K., Kwiecińska, B., Przetakiewicz, W., Pelczar M., 2015. Przyczyny wypadków i pożarów na statkach morskich. Causes of accidents and fires on marine ships. Zeszyty Naukowe Akademii Morskiej w Gdyni, 91, 21-29.

Gawdzińska, K., Chybowski, L., Przetakiewicz, W., 2017. Study of Thermal Properties of Cast Metal-Ceramic Composite Foams. Archives of Foundry Engineering, 17(4), 47-50.

Grabian, J., Gawdzińska, K., Szweycer, M., 2008. Behaviour of aluminum foam under fire conditions. Archives of Foundry Engineering, 8 (2), 41-44.

Jambor, M., Ulewicz, R., Nový, F., Bokůvka, O., Trško, L., Mičian, M., Harmaniak, D., 2018. Evolution of Microstructure in the Heat Affected Zone of S960MC GMAW Weld. Materials Research Proceedings, 5, 78-83. 
Kazienko D., 2018. The analysis of class survey methods and their impact of the reliability of marine power plants. Scientific Journals of the Maritime University of Szczecin, Zeszyty Naukowe Akademii Morskiej w Szczecinie, 55(127), 34-43, DOI: $10.17402 / 299$.

Kwiecińska B., 2015. Cause-and-effect analysis of ship fires using relations diagrams. Scientific Journals of the Maritime University of Szczecin, Zeszyty Naukowe Akademii Morskiej w Szczecinie, 44(116), 187-191, DOI: 10.17402/075.

Klimecka-Tatar, D., 2017, Variation of the morphology of the dental alloys structure under the effect of selected commercially available methods of thermal processing. Metal 2017: 26th International Conference on Metallurgy and Materials. 1806-1812.

Majewski, M., Kacalak, W., Budniak, Z., Pajor, M., 2018. Interactive Control Systems for Mobile Cranes. Advances in Intelligent Systems and Computing, 661, 10-19.

Marine Diesels, 2018a. Horror Stories Air Start Explosion On The Capetown Castle. Online: http://www.marinediesels.info/Horror\%20Stories/cape_town_castle.htm [Accessed: 23.11.2018].

Marine Diesels, 2018b. Operational Information: Air Start Explosions. Online: http://www.marinediesels.info/2_stroke_engine_parts/Other_info/air_start_explosions.h tm [Accessed: 4.11.2018].

Marine Insight, 2018. How to Prevent Starting Air Line Explosion on Ships? Online: https://www.marineinsight.com/marine-safety/how-to-prevent-starting-air-lineexplosion-on-ships/ [Accessed: 4.11.2018].

Myanmar Marine Engineers, 2018. Starting Air Line Explosion. Online: http://myanmarmarineengineers.blogspot.com/2015/06/starting-air-line-explosion.html [Accessed: 4.11.2018].

Ptak, M., Kaczyński, P., Fernandes, F., de Sousa, R.A., 2017a. Computer simulations for head injuries verification after impact. Lecture Notes in Mechanical Engineering, 431-440.

Piotrowski, I., Witkowski, K., 2003. Okrętowe silniki spalinowe. Trademar, Gdynia.

Ptak, M., Koziołek, S., Derlukiewicz, D., Słupiński, M., Mysior, M., 2017b. Analysis of the use of biogas as fuel for internal combustion engines. Lecture Notes in Mechanical Engineering, 441-450.

Sakow, M., Parus, A., Pajor, M., Miadlicki, K., 2018. Unilateral hydraulic telemanipulation system for operation in machining work area. Lecture Notes in Mechanical Engineering, 201519, 415-425.

Strojecki, S., 2011. Charakterystyka metod zapobiegania i gaszenia pożarów w zasobniku powietrza doładowującego wolnoobrotowych silników głównych. B.Sc. thesis, supervisor: Leszek Chybowski. Maritime University of Szczecin, Faculty of Marine Engineering, IESO, Szczecin.

Ulewicz, R., Novy, F., 2017. Fatigue resistance and influence of cutting technology on the mechanical properties of modern steels used in the automotive industry. Procedia Engineering, 192, 899-904, DOI: 10.1016/j.proeng.2017.06.155.

Yuzhong, S., Sasaki, S., 2003. Experimental Research on Explosion in the Diesel Engine Starting Air Manifold. ClassNK Tech Bull, 21, 49-53.

Zapłata, J., Pajor, M., 2016. The influence of presumed border conditions on FEM thermal analysis results based on the example of an LNG tank support saddle. Advances in Mechanics: Theoretical, Computational and Interdisciplinary Issues - 3rd Polish Congress of Mechanics, PCM 2015 and 21st International Conference on Computer Methods in Mechanics, CMM 2015, 601-604. 